\title{
Clarification Required for the Definition of Hepatitis B Virus Subgenotypes C1 and C2
}

\author{
Sang Hoon Ahn ${ }^{\mathrm{a}, \mathrm{b}}$ Lilly Yuen ${ }^{\mathrm{b}}$ Peter Revill ${ }^{\mathrm{b}}$ \\ ${ }^{a}$ Department of Internal Medicine, Institute of Gastroenterology, Yonsei University College of Medicine, Seoul,

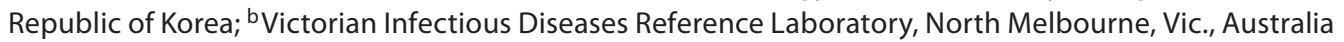

To the Editor

Hepatitis B virus (HBV) has been classified into 8 major genotypes $\mathrm{A}$ to $\mathrm{H}$, with an intergenotypic diversity of at least $8 \%$ in the full genome sequence. Genotypes A to D are the most common worldwide, with genotype A predominant in Western Europe, North America and Africa, genotypes B and C most frequent in Asia, and genotype D present in Mediterranean countries [1]. There is increasing evidence that HBV strains, even within the same genotype, differ in virological and clinical manifestation. Within the HBV genotypes, variability of between 4 and $7.5 \%$ has led to further classification into subgenotypes [1], although HBV subgenotypes are yet to be ratified by the International Committee for the Taxonomy of Viruses (ICTV) [2].

The HBV genotype $\mathrm{C}$ is prevalent in Asia, where it causes more serious liver disease than genotype B [3]. In the 2004 report of Norder et al. [4], phylogenetic analysis of 66 complete genotype $C$ genomes identified 4 groups of genotype $\mathrm{C}(\mathrm{C} 1-\mathrm{C} 4)$, with clear geographical clustering. The $\mathrm{Cl}$ subgenotype consisted of $\mathrm{HBV}$ strains from East Asia, including Japan, Korea and China, whilst the C2 subgenotype dominated in China, Thailand, Laos, Vietnam and Bangladesh. The C3 subgenotype was confined to New Caledonia and Polynesia and subgenotype C4 was confined to Australian aborigines in Northeast Australia. Subsequently, a C5 subgenotype has also been identified in the Philippines [5].

Fig. 1. Phylogenetic relationships of representative genomiclength HBV genotype $\mathrm{C}$ nucleotide sequences, showing the different classification system used by Norder et al. [4] and Huy et al. [6] for the same $\mathrm{C} 1$ and $\mathrm{C} 2$ sequences. The tree was generated using the Neighbour Joining Program in Phylip (http://evolution. genetics.washington.edu/phylip.html). Bootstrap analysis was performed using 1,000 data sets and bootstrap values are presented at the nodes. Each sequence is designated by its accession number and country of origin.

\section{KARGER}

Fax +41613061234 E-Mail karger@karger.ch www.karger.com
(C) 2009 S. Karger AG, Basel

0300-5526/09/0526-0321\$26.00/0

Accessible online at:

www.karger.com/int

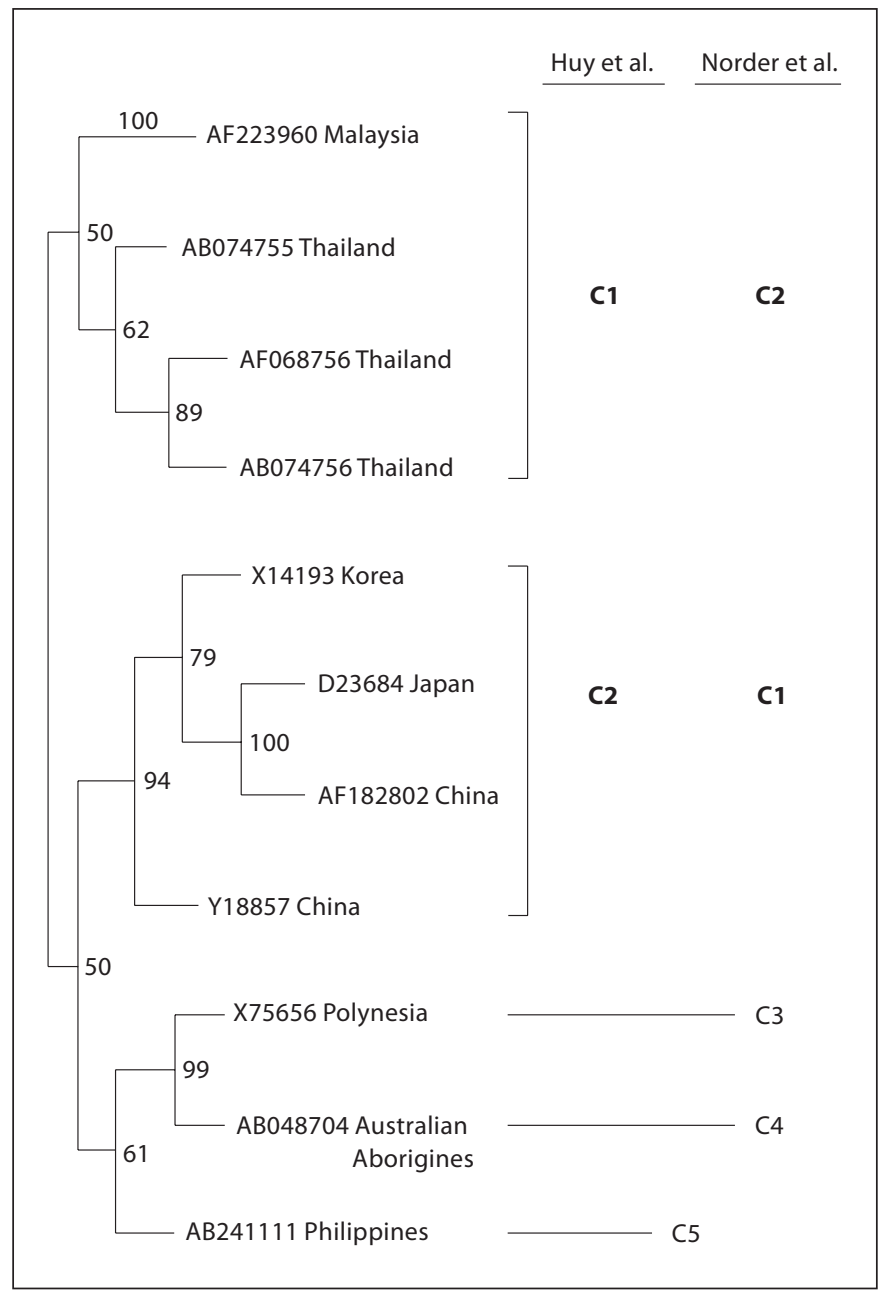

Peter Revill, $\mathrm{PhD}$

Molecular Research and Development

Victorian Infectious Diseases Reference Laboratory

10 Wreckyn St, North Melbourne, Vic. 3051 (Australia)

Tel. +61 39342 2604, Fax +61 39342 2666, E-Mail peter.revill@mh.org.au 
In 2004, Huy et al. [6] also characterized HBV genotype C from Asian countries. They identified 2 major subgroups within genotype $\mathrm{C}$ from 5 Asian countries: one for strains from Southeast Asia including Vietnam, Myanmar and Thailand (named $\mathrm{HBV} / \mathrm{C} 1$ ) and the other for strains from East Asia including Japan, Korea and China (named HBV/C2). Thus, the classification of $\mathrm{C} 1$ and C2 used by Norder et al. [4] and Huy et al. [6] differed. As shown in figure 1 , sequences classified as $\mathrm{C} 1$ by Huy et al. [6], were classified as C2 by Norder et al. [4] and vice versa. The methodology used in both studies was sound, however, the current definition of $\mathrm{C} 1$ and $\mathrm{C} 2$ subgenotypes requires clarification. Other studies have used a different classification system again, with
Chan et al. [7], designating the 2 subgenotypes as HBV/Cs in Southeast Asia and HBV/Ce in East Asia.

Most recent reports on HBV taxonomy and phylogenetic analysis have used the $\mathrm{C} 1 / \mathrm{C} 2$ designation from Huy et al. $[1,6]$, that is, $\mathrm{C} 1$ for the strains from Southeast Asia and C2 for the strains from East Asia. However, there is no categorical definition of which sequences belong to which subgenotype. In light of the emerging importance of HBV genotypes and subgenotypes in disease pathogenesis, we feel it is important that the classification of all HBV subgenotypes, particularly $\mathrm{C} 1$ and $\mathrm{C} 2$, are ratified by the ICTV, to avoid any future confusion.

\section{References}

1 Kramvis A, Arakawa K, Yu MC, Nogueira R, Stram DO, Kew MC: Relationship of serological subgenotype, basic core promoter and precore mutations to genotypes/subgenotypes of hepatitis B virus. J Med Virol 2008;80:27-46.

2 Claude M, Fauquet MM, Maniloff J, Desselberger U, Ball LA: Virus Taxonomy: VIIIth Report of the International Committee on Taxonomy of Viruses. London, Academic Press, 2005
-3 Chan HL, Wong ML, Hui AY, Hung LC, Chan FK, Sung JJ: Hepatitis B virus genotype $\mathrm{C}$ takes a more aggressive disease course than hepatitis $B$ virus genotype $B$ in hepatitis B e antigen-positive patients. J Clin Microbiol 2003;41:1277-1279.

-4 Norder H, Courouce AM, Coursaget P, Echevarria JM, Lee SD, Mushahwar IK, Robertson BH, Locarnini S, Magnius LO: Genetic diversity of hepatitis $\mathrm{B}$ virus strains derived worldwide: genotypes, subgenotypes, and HBsAg subgenotypes. Intervirology 2004; 47:289-309.

5 Sakamoto T, Tanaka Y, Orito E, Co J, Clavio J, Sugauchi F, Ito K, Ozasa A, Quino A, Ueda R, Sollano J, Mizokami M: Novel subtypes (subgenotypes) of hepatitis $\mathrm{B}$ virus genotypes $\mathrm{B}$ and $\mathrm{C}$ among chronic liver disease patients in the Philippines. J Gen Virol 2006;87:1873-1882.
6 Huy TT, Ushijima H, Quang VX, Win KM, Luengrojanakul P, Kikuchi K, Sata T, Abe K: Genotype $\mathrm{C}$ of hepatitis B virus can be classified into at least two subgroups. J Gen Virol 2004;85:283-292.

7 Chan HL, Tsui SK, Tse CH, Ng EY, Au TC, Yuen L, Bartholomeusz A, Leung KS, Lee KH, Locarnini S, Sung JJ: Epidemiological and virological characteristics of 2 subgroups of hepatitis B virus genotype C. J Infect Dis 2005; 191:2022-2032. 